Please note: This is an unedited pre-print version of this article.

\title{
Biofuel imaginaries: The emerging politics surrounding 'inclusive' private sector development in Madagascar
}

\begin{abstract}
Biofuels are just one of a host of bioeconomy initiatives which promise to deliver 'inclusive' sustainable development through innovations in bio-based products and services in the global south. Yet to critics, biofuels are seen as prime drivers in a global 'land grab,' rainforest clearance, and the dispossession of farmers. Responding to these concerns, firms in Madagascar have shifted production away from large plantations to small-scale production of the more 'environmentally-friendly' biofuel crop Jatropha curcas. Using a political ecology lens and building upon critical discourse analysis found in cultural political economy, I analyse perspectives of on the material effects and emerging politics surrounding a case of a British-biofuel start-up firm in the northwest Madagascar. I demonstrate that access to biofuel land and labour is dependent upon the inclusion of Malagasy in rural development projects. However, rather than delivering on the promises of biofuels, jatropha has largely emerged as a failed development strategy. This article examines the unaccounted for power that varied and diverse actors derive by promoting the inclusion of individuals and groups to share in benefits, and the material consequences of private sector development in the global south.
\end{abstract}

\section{Introduction}

In March of 2009, many in Madagascar woke to reports of armoured tanks roving the quaint cobblestoned streets of the capital city, Antananarivo. In the midst of a political crisis dissident army troops, who had switched allegiances from President Marc Ravalomanana to the former mayor and radio disk-jockey Andy Rajoelina, were manning the armoured vehicles. The political standoff led to what many in the media were calling a 'bloodless' coup d'état; that is, an effective transfer of power to Rajoelina's new High Transitional Authority. ${ }^{1}$ Yet after the immediate standoff subsided, around 50 lay dead and many more were wounded. ${ }^{2}$

While tensions around rising food and fuel prices had been mounting for a year, a major contribution to the political crisis came from a wave of populist anger over a controversial land deal made public. The now well-known deal in question awarded the South Korean

\footnotetext{
${ }^{1}$ The 2009 political crisis was seen as a power grab influenced both by domestic politics and external political dynamics, for more see Deltombe 2012.

${ }^{2}$ As it turned out, only one tank was actually deployed. Also, exact numbers of people killed are difficult to confirm, but best estimates range between 50 and 100 casualties.
} 
Please note: This is an unedited pre-print version of this article.

transnational Daewoo Ltd. a 99-year lease of 1.3 million hectares for export crops and palm oil for biofuels (Andrianirina-Ratsialonana et al. 2011). Rajoelina successfully mobilised waves of populist opposition by depicting Ravalomanana as 'selling off' land to foreigners for biofuels and export crops. ${ }^{3}$

Biofuels are just one of a host of 'bioeconomy' initiatives which promise to deliver 'inclusive sustainable development' through innovations in bio-based products and services in the global south. However, once seen as an environmental panacea, over the past few years biofuels have been subject to strong criticism from activists, academics, and environmental groups who claim its production is a primary driver of global 'land grabbing' and rainforest clearance, and that it inevitably competes with food crops (Dauvergne and Neville 2010; GRAIN 2013). ${ }^{4}$ In Madagascar, this critique has not gone unnoticed as many firms which began with much larger designs of vast plantations have either suspended their work or shifted towards much smaller production of the more 'environmentally-friendly' plant Jatropha curcas. Nonetheless, contrary to the urban protests that took place in the capital during the lead up to the crisis, outward manifestations of resistance in rural areas to biofuel land acquisitions have been fairly muted (although not completely silent c.f. Gingembre 2015; Medernach and Burnod 2013). ${ }^{5}$ Instead, some rural Malagasy are cautiously welcoming investors whose projects are seen as providing potential income opportunities, particularly where multilateral and bilateral development aid was previously shut off due to the crisis. ${ }^{6}$ It is within this milieu that private sector actors are subsidising rural development

\footnotetext{
${ }^{3}$ A stiff wave of opposition against land deals has been led by Malagasy NGOs and associations in urban areas - i.e., Collectif pour la Défense des Terres Malgaches - see http://terresmalgaches.info/ ${ }^{4}$ Land grabbing is defined by Borras and Franco (2012) as commercial land transactions and speculation by (trans-) national actors for use in biofuels and export food crops. ${ }^{5}$ I use the term land acquisition to denote land bought or rented for biofuel land deals.

${ }^{6}$ Since new elections were finally held in 2014 , there has been a slow trickle of foreign aid finding its way back into the country, though rural areas of agribusiness production have seen little of it.
} 


\section{Please note: This is an unedited pre-print version of this article.}

by building schools, delivering health care, fresh water, and improved crop varieties. They have, in effect, become de facto development agents in the process (Foucault ([1978]1991; Ferguson and Gupta 2002; Li 2007). While the private sector has been involved in infrastructure building and large-scale development for years in Africa and Madagascar, what is new is the increasing role foreign agribusiness and mining firms play in small-scale rural sustainable development (Lyons and Westoby 2014). Does this reflect a shift from what has been a development sector dominated by NGO and other civil society institutions? What are the emerging politics and material consequences of private sector development? What are the factors driving the promotion of biofuels and what does development look like after the biofuel rush?

This article's central aim is to draw attention to the emerging politics emanating from a discursive framing from the private sector of biofuel companies as 'post-development' agents. In doing so, this article directly addresses recent calls made for more robust theoretical and empirical focus on private sector development and its various implications in the global south (Oya 2013; Scoones et al. 2013; Argent and Measham 2014). To this end, I investigate the effects of the rise and fall of biofuel development through a case study of a medium-size British-owned startup called Vertifuel. Madagascar's seemingly available and cheap rural labour and 'underutilized' agricultural savannahs provided a good opportunity for start-ups like Vertifuel to capitalise on the island's expanding liquid biofuel sector. Access to land and labour, however, is not necessarily dependent upon direct exclusionary means of dispossession (Harvey 2003) as much of the land-grabbing literature suggests, but rather upon the 'inclusion' of Malagasy in small-scale development projects and promises of rural 


\section{Please note: This is an unedited pre-print version of this article.}

employment (Gingembre 2015; Li 2011). ${ }^{7}$ Results show that, over time, Vertifuel's development discourse was framed within an 'economy of appearances', defined by Tsing $(2000,118)$ as 'the self-conscious making of a spectacle' used to attract foreign investment, drive favourable investment policy, and moreover, ameliorate any resistance to its presence (Hunsberger and Ponte 2014; Tsing 2001; Jessop 2004). As with many other biofuel startups across the global south, Vertifuel's lower than expected output and eventual bust was due to a combination of factors including local acceptance of the project, poor performance of the crops and a sharp drop in global demand (The Economist 2015; Hunsberger 2010; Baka 2014). Empirical results show that meagre economic benefits were captured by a small group of migrant workers mainly due to their off-season labour availability and by local mayors who were able to negotiate land deals directly with the firm. These results provide fresh insights on the negative implications of homogeneous framing by the private sector of who development beneficiaries are without any critical analysis of socio-economic inequality and distribution.

Theoretically, this work integrates two distinct but relevant sub-fields: the first is political ecology, generally defined as the access and control over vital livelihood resources; and the second, cultural political economy, which examines the performance or construction, dissemination and legitimisation of knowledge around biofuel development (Neumann 2005, 1; Peet and Watts 1996; Leach and Mearns 1996; Adger et al. 2000; Schroeder 1999; Jessop 2004; Tsing 2000). Central to this task is investigating not just how global discourses and actors' performances surrounding biofuels converge and diverge, but the material implications on local 'environmental imaginaries' or "“truths," imagination, and discourses

\footnotetext{
${ }^{7}$ Much of the critical literature on recent land accumulation draws on Marx's oft-cited primitive accumulation or Harvey's related theory of 'accumulation by dispossession,' which is defined as a host of violent processes (forced evictions, privatization of land, formation of exclusive property rights etc.) that displace rural populations, divorcing them of their means of production in order to create a wage-labour class (Harvey 2003, 145).
} 


\section{Please note: This is an unedited pre-print version of this article.}

through which people think, speak, and experience systems of livelihoods' (Peet and Watts 1996, 37). I explore the ways in which biofuel discourse is operationalised within 'geographic space at the margins' (Moore 2000:409). This analysis helps shed light on the ways place-specific biofuel commodity production restructures 'material relations and condition[s] of rural life' including organising new divisions of labour and upending local customary land tenure relations (Cocklin et al. 2002, 2 quoted in Argent and Measham 2014).

\section{Methodological considerations}

Research from this article is based on two successive trips to biofuel sites in the Boeny Region in Madagascar's northwest Province of Mahajanga in 2012 and 2014. ${ }^{8}$ During this time, over 116 socio-economic surveys and semi-structured interviews we carried out with rural inhabitants and migrant labourers and 26 in-depth interviews with key informants including firm operators, plantation managers, local mayors and business elites. ${ }^{9}$ Discourse analysis and secondary economic data were compiled with the assistance of project managers and administrators of the National Land Offices and policy makers within Malagasy civil society groups. For comparison, primary and secondary data was collected from six other biofuel firms, some of which are still active and others which are now suspended or nonoperational.

The bulk of the semi-structured interviews were conducted with rural inhabitants who selfidentify with the Sakalava and Betsileo ethnic groups. ${ }^{10}$ Although ethnically distinct, these two groups have coexisted over a large geographic range across the northwest and central regions of Madagascar for hundreds of years. As we see below, their different livelihood

\footnotetext{
${ }^{8}$ Names of firms and informants reported were anonymised.

${ }^{9}$ This was done with the skillful assistance 6 locally hired Malagasy researchers.

${ }^{10}$ The Sakalava (est. pop. 700,000) are one of the 'group of 16' smaller ethnic groups who inhabit Madagascar, whereas the Betsileo (est. pop, 2 million) are second only to the Merina in total population.
} 


\section{Please note: This is an unedited pre-print version of this article.}

strategies-the Sakalava are mainly cattle herders while the Betsileo are primarily rice growers- are one of a host of factors (labour availability, wage, access, connections) influencing individuals' ability, or willingness, to participate in biofuel development schemes.

\section{Conceptual framework: performing bioeconomy imaginaries}

The bioeconomy is promoted by many as a 'transition economy which seeks to increase efficiency, optimize use and decrease environmental impact through the reduction of waste and greenhouse gas emissions. ${ }^{11}$ For years, advocates such as the EU have been promoting the use of agricultural biotechnology and new industrial innovations to 'engineer' an array of 'novel bio-based products and services,' including new forms of energy (biofuels), intermediate goods (biochemicals) and natural products (pharmaceuticals, bioplastics) (EC 2012).

Biofuel production has emerged out of this bioeconomy discourse as the proverbial 'winwin.' In theory, development planners claim that income derived from production will deliver a host of associated social and environmental benefits to local resource users, including people who work both in biofuels and surrounding areas of production. This 'inclusion discourse' is composed of a complex assemblage of donor agencies, environmental NGOs, and scientists who package biofuels for the 'circulation and orchestration' or 'alignment' of like-minded advocates (McDonald and Corson 2012, 161; Callon 1998). The articulation of the bioeconomy in this way parallels Jessop's (2013) 'economic imaginaries.' Jessop uses the cultural political economy approach of semiotics - defined as 'the social production of intersubjective meaning' - in order to better understand the 'social embedding

\footnotetext{
${ }^{11} \mathrm{EC}, 2012$, What is the Bioeconomy? Accessed at: http://ec.europa.eu/research/bioeconomy/policy/bioeconomy_en.htm (09/12/14).
} 


\section{Please note: This is an unedited pre-print version of this article.}

of economic and political relations' bound up in the assemblages of 'the economy' (Jessop 2004, 2; Mitchell 2008). These economic imaginaries comprise of 'social imaginaries and lived experience; the "economy" as an imagined ensemble of social relations; the instituted nature of the economy; and the contradictions, crisis-tendencies and counter-tendencies of the capitalist mode of production' (Jessop 2013, 3).

For Jessop and others, it is periods of economic and social crisis when the legitimisation project of neoliberal development crystalises, framing environmental, social, and political problems and solutions to them through the market (Birch and Tyfield 2012; Corson et al. 2013). However, couched under the banner of inclusive sustainable development, the integration of rural resource users into the bioeconomy leaves them vulnerable to periodic crises of capitalist accumulation (Moore 2010).

Development discourse surrounding the bioeconomy eventually materialises as a series of socioeconomic and ecological transactions which play out unevenly with rural economies. Fairhead and Leach note that seeing the economic 'landscape metaphorically' as 'text' or 'spectacle' allows us to view 'discursive fields linked to particular institutions [or groups], and how these, in turn help to shape socio-cultural processes' and the material effects on local environments and livelihoods (c.f. Igoe 2013; Stott and Sullivan 2000). Performativity is therefore not only a top-down process, but a lived experience permeating society at different scales. For example, Peet and Watts highlight the potential of local 'environmental imaginaries' 'or rather whole complexes of imaginaries' which can enhance, inspire and give institutional strength to resist through new social and political movements $(1996,37$;i 2007). While these 'local imaginaries' are powerful as a counter-hegemonic form of resistance, Forsyth reminds us that these 'discourses from below' can be easily co-opted and re-shaped by development actors and used to the advantage of powerful actors $(2003,158)$. I 


\section{Please note: This is an unedited pre-print version of this article.}

argue alongside Hunsberger and Ponte, who remark that we must continue ' $[\mathrm{u}] \mathrm{ntangling}$ and critically examining the relationship between discursive and material aspects of humanenvironmental interactions' if we are to better understand how powerful groups 'define meaning' $(2014,2)$, shape global environmental policy (Leach and Mearns 1996; Newell and Paterson 2010), and attract new markets and financial investment (Tsing 2000; Li 2014).

Until now, socio-environmental relations surrounding the bioeconomy within Madagascar have generally been examined with a focus upon the performance of state institutions and non-state actors and their effects on rural communities (Duffy 2006; Corson 2011). Corson (2011) and Seagle (2012) show how NGOs - particularly large environmental organisations

- have used discourse to secure their role as de facto grantees of locals' rights, within negotiations with the state over protected areas and mining enclaves, respectively. While in the past 30 years the NGO sector has been central in sustainable development programs in Madagascar, less highlighted is the increasingly influential role that the emerging private sector plays in mediating access to development benefits.

Indeed, elite actors, including mid- and top-level biofuel firm operators, are quickly becoming the new face of rural development in Madagascar. Consequently I investigate the representations and realities of discursive framing of biofuel development actors and the material effects in rural areas which tend to be diverse, multifaceted, and uneven geographically. Following Moore's interpretation of the spatial 'instabilities,' I examine biofuels development through the lens of political ecology to see how imagined bio'economies' and 'local ecosystems interact' in 'global margins' $(2000,401)$. The production of biofuels crops, much like previous historical and contemporary 'boom' commodity crops, such as rubber, cotton and sugar, are restructuring 'geographic space at the margins of the 


\section{Please note: This is an unedited pre-print version of this article.}

system in such a way as to require further expansion' (Moore, 2000:409; Harvey 2004; Marley 2015). For instance, organizing wage labourers and restructuring of customary land tenure arrangements are shaping and are being shaped by the promotion of new markets globally and the increased push to commodify new forms of nature, such as biofuels and other bio-based products (Lyons and Westoby 2014). The bioeconomy discourse helps to obfuscate the local and regional land and labour arraignments and other larger political economic drivers, such as flows of foreign capital (Fairbairn 2014), environmental governance regimes (Hunsberger et al. 2014; German 2012), and green economic investment and growth (Cotula 2012), which influence how biofuel benefits are gained, maintained and distributed.

\subsection{Making land investible for biofuels in Madagascar}

The rise of global demand for biofuels such as plant oil, biodiesel, and bioethanol was stimulated by a twin-set of alternative energy policies, the EU Alternative Energy Mandate and the US EP Act 2005 Renewable Fuel Standard (RFS) (German et al., 2011). The promotion of these policies by global environmental NGOs and national governments generated a biofuel rush and a host of large-scale land acquisitions in Africa and Madagascar driven by speculation about future demand (Carmody 2011; Borras and Franco 2012). In Madagascar, the investor rush also helped drive a host of 'fast-track' pro-business policies, including political-risk insurance, tax incentives and, most noteworthy, large-scale land tenure reform.

Yet, the Daewoo deal and subsequent political crisis in Madagascar demonstrates that meanings of land which were subsequently allocated for biofuels are contested and its values hold diverse meaning at the local level. Rarely do rural resource users hold formal property 


\section{Please note: This is an unedited pre-print version of this article.}

rights over their land, but rather maintain a host of customary and historical claims obtained through generations of ancestral lineage. ${ }^{12}$ The different local meanings and value of land ownership in Madagascar have posed significant challenges for foreign investment which is based on individual property rights (Burnod et al. 2013; Andrianirina-Ratsialonana 2011).

In response, there has been a concerted effort to try and 'tidy-up' land's messy and elusive characteristics in order to make it 'legible' for private sector investment in biofuels. Couched within modernising discourses of development and progress, this project of legibility can be viewed crucially as a way to bring land (and labour) into the circulation of capital through individual property rights and formalisation schemes (Li 2014; Scott 1998; Polanyi 1944). These efforts at making land investable for biofuels through formal means evokes Tim Mitchell's understandings of the making of 'economies' as '... a project, or series of competing projects, of rival attempts to establish metrological regimes' for purposes of exchange and accumulation (2002, p. 281). Here we see the work development discourse does in aligning and mobilising the delivery of market-based 'instruments' (e.g., land tenure and investment policy) to create to create private sector biofuel imaginaries and define rural development in the image of biofuel imaginaries and define rural development in the image of private sector's own making (Corson et al. 2013).

For example, many in the international donor community have been advocating the formalisation of property rights in Madagascar as a way to stimulate agricultural investments and increase foreign investment in both mining and agribusiness (World Bank 2010). Development economists and land policy specialists maintain that property rights can secure tenure and protect local environments, while simultaneously creating vibrant land markets for

\footnotetext{
${ }^{12}$ For further reading on Malagasy Ancestral ontologies see Ottino 1998; Feeley-Harnik 1991.
} 


\section{Please note: This is an unedited pre-print version of this article.}

rural producers (Deininger and Jin 2007). As noted by one of the largest donor-funded land tenure projects, the U.S. bilateral Millennium Challenge Account (MCA):

The Land Tenure Project is designed to increase land titling and land security, and improve the efficiency of land service administration. These will contribute to better land use, increased rural enterprise investment, and a better environment for collateralbased lending. ${ }^{13}$

Launched under the auspices of the GW Bush's Millennium Challenge Compact, the MCA included US \$109 million for financial sector reform, land tenure, and agribusiness promotion. These investments resulted in quite a number of new tenure laws, including a law (No. 2005-019) that declared that untitled private property was no longer under the ownership of the state, and a subsequent law (No. 2006-031) which certified long-standing customary claims to land, overturning years of centralised control (Teyssier et al. 2008). Both of these policies carry immense grassroots support, mainly due to their recognition of locals' customary claims to land and the opening of municipal offices (guichet foncier) to guide claimants through the process. The initiative was meant to provide tenure security at the community level through a certificate foncier (local land certificate), while also combatting land seizures and forced evictions (Teyssier 2010, Andrianirina-Ratsialonana et al. 2011). ${ }^{14}$ However well-meaning, these approaches have been stalled from being fully implemented in many rural municipalities due to the longstanding political crisis, but also a political unwillingness by many state land institutions to embrace decentralised land rights.

One main drawback from the launching of these new laws is that legally there are a number

\footnotetext{
${ }^{13}$ Millennium Challenge Compact, Madagascar https://www.mcc.gov/where-wework/program/madagascar-compact (12/11/15). Emphasis added.

${ }^{14}$ This push to formalise customary claims should not be underestimated; it represents a diverse spectrum of domestic groups which eventually built alliances with international multilateral and bilateral agencies and institutions looking to deliver property rights to individuals and communities.
} 


\section{Please note: This is an unedited pre-print version of this article.}

of different agencies that can now claim to provide access to land for agricultural investment, including the Ministry of the Interior and Decentralization; Ministry of the State Presidential Projects, Spatial Planning and Equipment; Ministry of Agriculture, EDBM; regional government municipalities and the local land bureaus (Burnod et al. 2013, 361). Even with a renewed push to review the implementation of the new land laws since the end of the crisis, there remains significant confusion about the certificate programme at the local level; and much of the influential decision-making still remains in the hands of rent-seeking regional, local private sector actors and local mayors. Furthermore, the simultaneous promulgation of laws designed to bolster foreign direct investment and to facilitate land titling for agribusiness in rural areas has sent mixed messages. For instance, this push for more FDI was topped off with the implementation of an investment law (No. 2007-036) and the establishment of the Economic Development Board of Madagascar (EDBM). Essentially, the EDBM was an initiative to 'fast-track' foreign investment, which during its initial phase (2007 - 2010) increased FDI inflows roughly 13-fold (UNCTAD 2011). This investment law also gave the EDBM the role of administering large-scale land acquisitions for foreign-owned agrofuel production in the Ministry of Agriculture's selectively zoned Agricultural Investment Areas (AIA) (Burnod et al. 2013). As stated in the law, for foreign investors to obtain land for biofuels they must register a state titled plot of interest or find untitled and/or unoccupied areas which can be transferred via lease or sold from private owners. Many of these new investment policies and land tenure laws are relatively unknown to many Malagasy, adding to the complexity and confusion over who has the authority over land management decisions at the rural level. As we see below, this confusion actually provides an opening for private sector actors to now negotiate both formal and informal access to land and labour at multiple institutional levels simultaneously. 
Please note: This is an unedited pre-print version of this article.

\subsection{A snapshot of jatropha in Madagascar}

Jatropha curcas is a low-lying pantropic shrub which propagates wild on semi-arid soils in savannas and steppe ecosystems. The plant's parts are used to treat skin ailments and as an antiseptic, and they are also used as a live fence against livestock. More commonly, jatropha is planted worldwide for the industrial production of liquid biodiesel. It is promoted by planners and green-energy firms as sustainable since it has the potential to produce alternative fuel while not competing with food crops as with other purpose-grown feedstocks (maize, sugarcane and palm oil) (see Openshaw 2000; Pandey et al. 2013). ${ }^{15}$

For years, the broad dry savannahs of Madagascar's western and southern regions have been endorsed as an ideal environment for jatropha. This comparative advantage led development agencies to set up a host of pilot biofuel projects throughout Madagascar in the early 2000s. At this time, firms such as D1, GEM, and JSL Biofuel received startup help from USAID and other bilateral donor groups who were looking to biofuels as a way of generating income and promoting sustainable development (BAMEX, 2008). Most of the biofuel strategy was driven by a large United States Agency for International Development-funded platform (BAMEX), which at the time marketed and developed a network of agri-businesses to begin the establishment of jatropha-based schemes and a framework for biofuel policy (Sustainable Agrifuels National Platform (PAD)) introduced the National level with the help of Environmental NGOs, such as World Wildlife Fund (WWF). ${ }^{16}$ Evidence of the promotion of biofuel development discourse is prolific. For example, in a BAMEX document under the sub-heading 'Madagascar Positioned for Success in the Jatropha Market' it read:

\footnotetext{
${ }^{15}$ For alternative views on the environmental impact of Jatropha see van Eijck et al. 2014.

${ }^{16}$ Since 2012, a Sustainable Agrifuels National Platform (PAD) has been introduced to provide a framework for biofuel policy in Madagascar at the National level.
} 
Please note: This is an unedited pre-print version of this article.

Many regions throughout Madagascar have very favourable conditions for cultivating jatropha. Today it is commercially farmed, although most projects are operating on a pilot scale. D1-BP and GEM Biofuels, which are listed at the AIM stock market in London, operate in Madagascar. A further nine commercial ventures have been identified in the course of this study. It is expected that Madagascar will be a major jatropha oil producer in the future. ${ }^{17}$

And echoed by a separate BAMEX document:

BAMEX's achievements in the promotion and development of the jatropha industry have had a direct impact on the economy of Madagascar... [c]reation of jobs caused by the presence of investors...the installation of new foreign investors contributes to improving the climate investment... around 104,000 direct jobs caused by the establishment and operation plantations...several thousand additional jobs will be indirectly created by the development of related activities...[i]ncrease FDI flows through a contribution valued at $\$ 100$ million USD... ${ }^{18}$

There is also, however, a counter discourse which in Madagascar (and globally) have mobilised a wave of activism against what they see as false promises of inclusive development through foreign land acquisitions. As noted by an international activist on land issues surrounding the firm an Italian agribusiness firm Tozzi Green in Madagascar:

In Madagascar, land grabbing is caused by foreign and domestic investors implementing agribusiness projects and setting up biodiversity conservation areas, but also developing tourism and extractive industry infrastructure...We are currently supporting pastoralist communities' claims against...jatropha for agrofuel production. ${ }^{19}$

And by a local farmer in the same area:

They gradually expanded their cropping areas and are using our own lands now. We, small farmers, are obliged to leave because there are armed people who are evicting us from our lands. The loss of grass where zebus can graze is leading to the death of our animals on the spot. They have destroyed the graves of our ancestors. Our sacred places have been destroyed by tractors. ${ }^{20}$

It may be argued that while the early 'win-win' discourses of biofuels seemed to have won

\footnotetext{
${ }^{17}$ WWF-funded Global Market Study on Jatropha, May 2008 (BAMEX 2009, 17). Italics added.

${ }^{18}$ Evaluation externe du BAMEX - Rapport final - Hermès Conseils - Avril 2008. (10/1/2015).

${ }^{19}$ Collectif pour la Défense des Terres Malgaches - see http://terresmalgaches.info/

Cited in Rakotondrainibe 2012, 1. Italics added.

${ }^{20}$ Cited in Rakotondrainibe 2012, 1.
} 
Please note: This is an unedited pre-print version of this article.

out, some of these more critical voices have definitely had an effect on how operators work in Madagascar. Shifts from large scale production of biofuels in Madagascar especially after the Daewoo deal and moves to regulate production can all be seen as reactions to put a more sustainable face on production. More noteworthy, as we see below, firms are also evolving as they seek to limit their environmental and social externalities through the delivery of development services. Although difficult to make a direct correlation, critical local discourses seem to be having an effect on raising awareness to the potential negative effects of biofuels.

For instance, in 2009, the total land targeted for the production of biofuels in Madagascar was estimated at between 880,000 and 1.1 million hectareage (WWF 2011). However, today within this range, there are less than 60,000 ha actually under production. This demonstrates that most projects remain either in the planning or suspended stages of operation rather than production. A 2011 survey conducted by the World Wildlife Fund for Nature (WWF) found roughly 56 biofuels projects either in preparation, or temporarily suspended with only a few actively producing biofuels. More recent data from 2015 from the International Land Matrix corroborates a similar trend showing the total jatropha ha for the top six biofuel producers well below the intended or contracted size (see table 1). The majority of these six projects is located in the reasonably dry sub-humid regions of Boeny, Diana, Ihorombe, and Sofia. The largest of these jatropha producers included an Italian firm called Tozzi Renewable, which before it ended its biofuel production in 2014, operated across 2000 ha in Ihosy (See Table $1)$.

\section{Insert table here}

Although the biofuel industry is not particularly sizable when compared to recent biofuel investments observed across Africa and Asia, the potential impact on Malagasy agrarian 


\section{Please note: This is an unedited pre-print version of this article.}

societies is still significant. Roughly 72 percent of Madagascar's 18.5 million inhabitants rely on rice or pastureland agriculture for both subsistence and direct income. ${ }^{21}$ Therefore, any rural land acquisition has implications for access to land livelihood resources, such as irrigation water, pastureland and forest products. For example, recent foreign investments in agribusiness and mining have shown mixed results in delivering on promised benefits and have, in some cases, produced negative effects on livelihoods, including the increase of rural tensions and the loss of access to vital resources (Ramaroson et al. 2010; AndrianirinaRatsialonana et al. 2011; Medernach et al. 2011; Seagle 2012; Franchi et al. 2013). As noted above, many rural inhabitants do not hold official titles to land or forest resources they use, but rely instead on kin-based customary claims. These customary claims hold immense cultural and social value for Malagasy, who see their surroundings as a direct line to ancestors and provide authenticity against counter-claims (McConnell 2002). ${ }^{22}$ Nevertheless, until recently, customary claims were often not recognized by government institutions and, as such, there is frequent confusion about resource tenure security and an anxiety about the possibility of eviction to make room for biofuel investment schemes (Evers et al. 2011).

\section{The imaginary of private sector development: Vertifuel in Madagascar}

Vertifuel began preparing their jatropha plantations in 2009 with the intention of producing fuel for international and domestic markets. Extensive interviews with the CEO of Vertifuel, Alex, reveal the range of optimism of the benefits of expanding production from its current

\footnotetext{
${ }^{21}$ Many survive on roughly $\$ 1.25$ per/day.

${ }^{22}$ Resource users have over the years developed particular 'tenure niches' are not static entities, but rather, as McConnell (2002) remarks, are constantly developing in response to, and in accordance with, micro/macro political economic, ecological, and social change (see also Bruce et al. 1993, 627).
} 
Please note: This is an unedited pre-print version of this article.

500 ha to its target range of 5000 ha. ${ }^{23}$ This target was vital to secure financing from foreign banks and individual investors mainly from the UK which were looking for large-scale operations that would guarantee profitability within the first few years. As noted by a senior investor, 'you've got to make something that makes money and that is going to actually get the support of the bank and get the support of investors, otherwise you're just wasting your time. ${ }^{24}$ However, for Vertifuel and similar firms, they are quick to point out that the production of biofuels in Madagascar goes beyond profitability, but doing something more meaningful, as noted by Alex:

[Development]Benefits are proving that you can take eroded land and produce green oil, create employment, improve healthcare, improve education, break the poverty trap that has influenced this country, particularly this area for the last 100 years. And to do so, without requiring aid, but doing it through a private sector initiative, demonstrating that you can make money, but also help people change the way they do things, and act as a catalyst for other people to do things which are similar. So it's first and foremost to make money, it's a business proposition, but at the same time it's also there to make a difference to people's lives...we don't need less Vertifuels in Madagascar, we need thousands more companies like it.

Vertifuel is not alone in its promotion of private sector development, as hype surrounding

biofuels can also be found by other even larger firms in Madagascar:

This mission of providing social services for access is obvious for a large firm which is part of a larger alternative energy conglomerate working in over 10 different countries, and with plans to convert over 100,000 ha to jatropha biofuels in the next few years...In addition to the availability of land, the abundant Malagasy workforce is currently just begging to be valued...In return, the company has committed itself to improve the living of that labour force through job creation, rural development, rehabilitation of schools and food security. ${ }^{25}$

In fact, the performance of development is vital for firms. Beyond profitability, investors want to hear that their money will contribute to enriching local Malagasy livelihoods,

\footnotetext{
${ }^{23}$ The firm has formal rights to 1700 ha and 300 ha of privately owned land at their disposal for jatropha production. The majority of this land overlaps with both local Sakalava pastureland and some local Betsileo rice plots and pasture.

${ }^{24}$ Anonymous interview 20 (July 7, 2012).

${ }^{25}$ Ratisimbarisoa 2012, Accessed on April 2012 at: http://www.tozzigreen.com/?lang=en
} 


\section{Please note: This is an unedited pre-print version of this article.}

particularly as they see multiple press reports surrounding rainforest clearance and farmer evictions due to global biofuels. Domestically for the firm, the perception that biofuel investment can deliver development accomplishes two things: first, it provides political cover for regional elected officials and local land administrators who administer the contentious land leases and development plans; and second, it helps quell local resistance (albeit temporarily) of those who may be excluded from labour opportunities and/or can no longer access land which is now being used to grow biofuels. As noted above, for the firm, biofuel production has become more than just an agricultural venture, but a wholescale social transformation of rural communities by the private sector. No longer is development incumbent on the state or civil society, which for the past 25 years have been a mainstay in rural communities across Madagascar. Instead, according to firm operators, it is the private sector that has come to provide vital social services, as discussed by Alex:

While I agree there has been an increasing movement away from responsibility by the state... It's been placed upon the private sector, development is for anyone who is around and prepared to pay the bill...from the private sector point of view, what we're doing actually is not aid, it's not charity, and it's simply common sense. Because I want to make sure that the people who work for me are people who are well, are healthy, they're reasonably educated, and they're more efficient - to do a reasonably good job as well as being able to work for themselves. ${ }^{26}$

For some, the delivery of health and education, alongside the building of schools, roads and much needed water systems, ostensibly represents a 'natural' progression of the private sector's role in taking over rural development from NGOs. It has become part of the rural biofuel development imaginary characterising much of rural Madagascar (see Seagle 2012).

He continues:

...in the last 3 to 4 years there has been a massive retreat by the aid agencies responsible for nearly 70 per cent of the income of this country. Which tells you something to start with, it's the wrong way! But the fact is that they've retreated and there's been no parachute ... and rightly so the private sector is taking over the mantel of

${ }^{26}$ Anonymous interview 7 (July 21, 2012). 
Please note: This is an unedited pre-print version of this article.

responsibility...so in addition to that we'll also have, as you would imagine a social program, where we have built 2 schools which you'll see. We've built a medical clinic...we are now one of the major employers in the region. ${ }^{27}$

For local elites, such as mayors who are looking to capture rents and curry favor and political capital from the projects, the speed at which they see the private sector operating far exceeds that of Malagasy public institutions, aid agencies and even many large NGOs. As one local mayor noted, 'the private sector is much more flexible, can make decisions at the local level and allows for 'on the spot' decision making.' ${ }^{28}$ This flexibility to expand infrastructure and to make other decisions regarding production also opens the door to questions surrounding transparency, as many “on the spot” decisions do not filter through government administrators. While not stated explicitly, many believed that local mayors were collecting informal rents to help hasten the time it takes to get local consent for project planning. For example, as one Vertifuel plantation manager told me:

We work with a local man who has a deal with the local authorities, but my sense was that this could take too long. We now need to move quickly because we're now looking at major extension of the project, so what is our major extension? We are having roads which are being specifically created for us. As of next Monday they are being built and that will take 2-3 weeks. ${ }^{29}$

This was again echoed to me by the mayor:

What the state provides us takes four years to get and I can have that within one month with private funding. For development agencies, it takes two years for what I can get in two days with private funding. ${ }^{30}$

This exemplifies the way in which local mayors are seen performing biofuel imaginaries.

However, pro-agribusiness discourse can also be seen at the highest levels of government, as shown in a recent visit by the current President of Madagascar to the site of Tozzi Green - a large agricultural investor in the south of Madagascar:

\footnotetext{
27 Anonymous interview 12 (July 19, 2012).

28 Anonymous interview 20 (July 7, 2012).

29 Anonymous interview 17 (July 6, 2012).

${ }^{30}$ Anonymous interview 20 (July 7, 2012).
} 
In his speech set out in the rural Commune...the President stressed his strong interest in government deals with investors like Tozzi Green... where no one has ever dared before investing, but which is nevertheless a prosperous region where livestock is as important as agriculture and where land is arable and available... [The President's] "thanks" stressed unequivocal support, while addressing an invitation to the public to trust the company... as a model for large-scale agriculture. ${ }^{31}$

Yet even with all of the advantages, the use of private capital to subsidise development in Madagascar and elsewhere has shown to develop unevenly across the rural landscape and at best with mixed results (Seagle 2012; Gingembre 2015). Unlike traditional donors such as NGOs or the state, private sector money is linked to its global finance networks (banks, individual investors) from which it draws capital for the firm's development activities. This model of development is particularly risky in private sector agribusiness or mining, when profits may be tempered by a host of endogenous factors, such as production and labour costs, bad weather, or global commodity prices, which may obstruct how much firms are willing to invest or commit to particular sites. As I demonstrate below, the significant drop in demand for biofuels in the past few years has caused a decline in development investment and a restructuring of target populations meant to benefit from production.

\subsection{Shifting biofuel imaginaries}

In late 2011 Vertifuel, alongside other biofuel firms, ran into production troubles. ${ }^{32}$ Although for years the plant heavily promoted a 'silver-bullet biofuel' which was said 'to flourish' in Madagascar, the reality was that jatropha needed large amounts of water and nutrients which are not readily available in the western savannah regions (van Eijck et al. 2014). ${ }^{33}$ Firms began to produce on land promoted by development agencies which was generally held under

\footnotetext{
${ }^{31}$ Accessed at: http://www.tozzigreen.com/le-president/ (18/11/15).

${ }^{32}$ Due to this slowdown, Vertifuel began to supplement its biofuel production with commodity crops (legumes, corn and red peppers) for export to Mauritius and for regional markets.

${ }^{33}$ This decline continues until today. Vertifuel's output in 2013-4 was just over 15 tones, which is a literal 'drop in the bucket' in terms of the hundreds or thousands of tones needed to support any medium to large-scale production sector.
} 


\section{Please note: This is an unedited pre-print version of this article.}

customary tenure. This presented problems as these customary holdings were not formally recognised and were targeted as opportunities to get foreign investors to develop 'underproductive' and marginal land. In some of the areas studied contradictory and overlapping land tenure claims have created layers of mistrust among rural Malagasy who from the very onset questioned the transparency of the Vertifuel deal. ${ }^{34}$ One of the many effects of this uncertainty has been for some to question the social sustainability of biofuels and other forms of foreign investment not just near Vertifuel, but across Madagascar (Rakotondrainibe 2012; Franchi et al., 2013). This turn against biofuels was noted by Alex:

You know, 3 years ago, I was in banking and now I'm in biofuels. And about 2 years ago, everybody thought what an interesting person, how imaginative. You know a distinguished financer who is trying to also learn about climate change and saving the planet. What a charming man and so I was getting all these dinner invitations. And now many just say, 'banker, biofuel, and regarded as an axe murderer!' I haven't been invited anywhere, not even for a cup of tea! ${ }^{35}$

One strategy adopted by firms to diffuse local conflicts was to shift production size from large plantations to smaller areas of 'refused' or marginal plots not being used by locals. For the firms, the geographic shift opened up possibilities to tap into new labour pools and underutilised 'open access' plots. Unbeknown to Vertifuel's managers, much of the 'underutilised' pasture land offered to them by local authorities already holds long-standing customary and sometimes contested claims. These customary claims are often not recognised by state officials (Raison 1969; Ramaroson et al. 2010). As one Vertifuel manager noted, 'I will not recognise any claims unless people have absolute cast-iron paperwork, which in most cases they don't. ${ }^{36} \mathrm{He}$ went on to state:

\footnotetext{
${ }^{34}$ Officially there are eight local land offices in the communes surround Vertifuel, but very few of them are very functioning and many exist on paper only, and have had very little effect on the firm's decisions to access more land. It is important to note that few locals had knowledge of local land offices or thought of using them to resist the firm in any way.

${ }^{35}$ Anonymous interview 9 (July 6, 2012).

${ }^{36}$ Anonymous interview 9 (July 6, 2012).
} 
Please note: This is an unedited pre-print version of this article.

I'm not interested in owning land in Madagascar. I'm interested in using the land to grow plants. [...] of course as soon as a devoted white man appears, with some money to invest, suddenly, and you get a whole load of people suddenly showing up saying, "Oh, that's my land!" So where's the paperwork? Well, the paperwork of course, doesn't exist. ${ }^{37}$

After some early confrontations with locals claiming they had been expropriated, firms were beginning to understand that a shift in the discourse and approach towards a less combative relationship with local resource users might be best. As noted by a former firm plantation manager:

...the acquisition of land changed very much in that the central government took a far more involved role in acquiring land. We wanted it on a lease. We needed to manage the plantation ourselves, so what we would do is we would go along to the municipality and we'd ask them to call in local authorities to have a public meeting to talk about what we wanted to do and ask them if they were interested in it.

Interviewer: So it was a sort of, consultation meeting?

Yeah! And it was the best thing since sliced bread to them. They've never had anybody ask them or consult them about anything before. They've been used to people sort of coming along, foreigners, and parking their spaceship, so as to speak, on their land... ${ }^{38}$

Yet for many, consultation meetings like this never took place. In reality, Vertifuel CEO separately negotiated access to land through two routes. The first was through formal means at the municipal state land services, which after long delays, finally granted the firm a 30year lease. Second, the firm worked out informal negotiations with the mayor, the head of the Fokontany (or village head) and some community members (Medernach et al. 2011, 5). According to the mayor, these 'deals' between the firm and local included discussion about development services which the firm could bring in which were contingent on their approval. In the end, Vertifuel work began without the state's legal authority but with the mayor's blessing. However, many understood that the land deal was primarily an agreement between the mayor and the firm and that the meeting was to re-affirm the agreement:

\footnotetext{
${ }^{37}$ Anonymous interview 11 (July 9, 2012).

${ }^{38}$ Anonymous interview 23 (July 19, 2012).
} 
Please note: This is an unedited pre-print version of this article.

The mayor said things about an agreement, and there have been discussions about something. But the money never came out after. The mayor gathered people and said that there will be a project coming here. He said a lot of things that time. But when they arrived, they didn't inform the Fokontany [villagers] or the Fokonolona [village leader]... We felt betrayed. Because we were told that they would come to talk with us. But when they arrived, no one ever came to talk with us. We never saw their faces.

It was at this time, that many in the area soon found out that the firm's promises were probably not going to materialise. And while even from the outset most did not buy into the biofuel imaginaries, some were rather hopeful that they could get at least some services out of the project that they now lacked since the crisis. I asked Lana, a woman farmer in the region, if the firm promised anything in return for their land: 'they [Vertifuel] promised a school. They gave a letter and agreed to make a school. The land is here, but up to now, there is no school. ${ }^{39}$ Although hopeful in the beginning, the school and the lack of a real wage were just one of many undelivered promises in the area and her reaction reflects the frustration that many are now feeling about the firm's presence. This frustration is explained by Robert, an older herder in a village farthest from the plantation:

Yes, when they arrived, they said they are going to make the school, a hospital, and dig canals to control flooding. But when they arrived, they didn't even call the mayor or the president of the Fokontany. They immediately started to make the plantation... we tried to act and resist but we couldn't... so we negotiated first a school and then hospital, and wells for all the villages in the sector. But now there is only one clinic and school, only really servicing those close to the centre. ${ }^{40}$

The failure of benefit delivery was made particularly clear to me when Patricia, a woman farmer, expressed her desperation over years of hearing from those who promise development in the area, 'we always come here and talk and answer questions about what we want...you then leave and we are left with nothing. ${ }^{41}$ Patricia's understanding of development is by no means static, but an assemblage of dynamic responses to multiple experiences of colonial, state, civil society and now private sector development agencies who

\footnotetext{
${ }^{39}$ Anonymous interview 21 (July 6, 2014).

${ }^{40}$ Anonymous interview 14 (July 14, 2014).

${ }^{41}$ Anonymous interview 23 (July 4, 2014).
} 


\section{Please note: This is an unedited pre-print version of this article.}

through local consultation seek out the affirmation of their own visions of 'how development should look' (West and Carrier 2006; MacDonald and Corson 2012).

Perreault explains that foreign firms' "“[c]onsultation mechanisms” - like many forms of "participatory" development - functions as a sort of performance, in which state officials, and company representatives, and community residents all play a role in what amounts to a carefully managed and highly predictable process '(2014). ${ }^{42}$ For the firms, the payout of these 'consultations' is the selection of local elites (and sometimes even elected mayors) that can be 'slotted in' as biofuel 'agents' which, as one government official at the National Land Office noted, can set up profit-sharing agreements and intermediary purchasers of land. ${ }^{43}$ Such local wealthy businessmen can buy, sell and/or rent land directly for foreign use. These mediators, some working as government consultants, also provided services and access to local mayors and representatives so as to promote the firm's activities (see AndrianirinaRatsialonana et al. 2011). For this to occur, local mayors must sign off on any project coming into the commune and act as the liaison between communities and firms. The mayors are central in local land planning and management councils, which are charged with conducting land surveys for agribusiness production, and thus they are knowledgeable and have access to information as to who holds customary land rights. This newly acquired power has elevated their standing in certain communities while diminishing their authority in others (Burnod et al. 2013). In some cases, there have been concerns that the mayor was using the 'tools of the guichet foncier to prospect land for himself. ${ }^{, 4}$ Although it was difficult to confirm, there is a growing perception amongst rural inhabitants that since the mayor is charged with

\footnotetext{
${ }^{42}$ Perreault, T. 2014. Mining, power and the limits of public consultation in Bolivia's mining sector. Accessed at: http://ppel.arizona.edu/?p=847 (08/09/15).

${ }^{43}$ This dynamic of elite capture of land and rents was explained to me by a land rights civil society advocacy group based in Antananarivo in collaboration with the International Land Coalition and was confirmed by a leading official working for the based in the Ministry of the Interior.

${ }^{44}$ Anonymous interview 3 (July 11, 2012).
} 


\section{Please note: This is an unedited pre-print version of this article.}

demarcating plots under the local land use plan while also negotiating the commercial terms with firms, he is in a position to make favourable deals and to prospect new ones (Medernach et al. 2011; Ramaroson et al. 2010). This elite capture of benefits, mainly by mayors in the form of land rents and political influence, from land deals is just one of the outcomes of the restructuring of social and material relations as the private sector biofuel development 'deepening and widening' commodity relations within the spatial margins (Moore 2010, 410). A second, whom we turn to next, is that of the instabilities that arise through the promises of rural employment and the new divisions of labour in biofuels (Oya 2007).

\subsection{Delivering employment and restructuring a labour force}

A continuous boast from biofuel firms is that they provide income-generating work to a local labour force. While one Vertifuel worker claimed that they are responsible for up to 500 seasonal jobs now, this number will increase to at least 2000 as the firm expands in the near future. ${ }^{45}$ Yet after Vertifuel's initial establishment of the plantations, the firm kept only 150200 permanent employees. Over time however, as biofuel demand slowed, not only did the numbers of employees decrease but Vertifuel also altered its hiring strategy. Instead of hiring 'local,' the firm began employing migrant workers from the neighboring city of Marovoay (a large rice growing area roughly $40 \mathrm{k}$ to the west). ${ }^{46}$ Almost overnight a permanent migrant labour camp grew next to the plantation site. This 'migrant village' now holds about 60 houses with a population of about 150 semi-permanent and seasonal contracted workers. The migrants living in it are mainly from the Betsilio (rice growers) ethnic group, whereas most people living in the area are Sakalava (mainly mobile cattle headers of a sub-species called

\footnotetext{
${ }^{45}$ Anonymous interview 10 (July 7, 2012).
} 
Please note: This is an unedited pre-print version of this article.

$z e b u)$. A local Sakalava resident discussed the reasoning behind the use of the migrant

Betsilio as waged labourers:

Tsri: The locals here don't really like to work for the firm. There're more people not originally from there that work. To tell the truth there are many Sakalava from here. They don't want to work for this company actually. Because the salary is very small, they prefer working with their zebu. They produce rice and they are wealthy with zebu.

Interviewer: How much did they get in salary?

Tsri: It used to be 6000Ar per day. So it worked. But then they made it 4000Ar. The people [migrants] work there because they are poor. They don't have enough, so to have some money for the family.

Interviewer: So you still happy with them being here?

Tsri: Yes, so far. But the salary is too low. The firm needs them, but the salary is too bad and the firm's promises of work and better wages are the problem.

Many of the firm's labour opportunities are designed for migrant seasonal labour because they have long periods where they do not need to attend their rice fields and thus can devote to the jatropha work. ${ }^{47}$ However, over 50 percent of both the migrants and those living within the three villages surrounding the plantations reported that their financial situation 'got worse every year' since Vertifuel began production. The decrease in economic conditions can more generally be explained by the political crisis which had the knock-on effect of increasing prices of everyday products such as such as rice and sugar. While deteriorating economic situations could not directly be tied to the firm's presence in the area, biofuels did not provide much in the way of increased income generation or consistent development services which could be shared or by any means be inclusive.

Only 14 percent of the migrants reported that work with the firm helps even out their expenses and 36 percent say it provides some added cash to their savings. While the majority of the benefits of development seemed to favour migrants who worked directly for the firm, very few actually said that they were able to take advantage of any of them. Although 50

\footnotetext{
${ }^{47}$ One kilo of jatropha seed costs around 85-175 Ar. (US\$ 0.03-0.06). Wages can vary between 35000 Ar. per day (US\$1.25-2.20). For a 6 day working week at 8 hours per day, this amounts to roughly 75000 to 112,500 Ar. per month (US\$ $31.25-49.73$ ).
} 


\section{Please note: This is an unedited pre-print version of this article.}

percent of migrants responded that the firm has 'sympathies to their daily needs' (as compared to 14 percent for non-migrant villagers) few saw any improvement to schools or health services. Many of the migrants did note improvements to roads ( 76 percent) and water services (25 percent) though none mentioned any increase in overall quality of life. Some reasons for this negative reflection on the firm by many of the locals are due to the distance from the plantation site where most of the services sit and the inability for them to capture many of the benefits directed solely for firm workers. Also, many felt that they were not entitled to these services because they did not work for the firm. While a few said that the development projects selected were appropriate, some did mention that they told the firm that a bridge in the areas was more appropriate due to flooding in the area. Most noteworthy, however, is the number of villagers who said that in the end, a fair price and consistent work particularly during the hardship periods between harvests (known locally as periode de soudure) would have been the best thing that the firm could deliver. Yet, even with all of the failed attempts to bring services and with all the dissatisfaction amongst villagers, it seems that the firm remains determined to show their successes in development. In the end, the firm was not a savior by any means, but a hindrance to their everyday livelihood struggles.

\section{Discussion and Conclusion}

The aim of this article is to address calls for more theoretical and empirical analysis on the various effects of private sector biofuel development in the global south (Argent and Measham 2014). Analytically, it integrates two distinct but relevant subfields: political ecology and critical political economy. In doing so, it demonstrates the effects of 'imaginaries' or the 'economy of appearances' surrounding biofuel production in Madagascar as they converge and diverge from local understandings of private sector-led development (Tsing 2001; Jessop 2004). Theoretically, this is congruent with Corson et al.'s term 


\section{Please note: This is an unedited pre-print version of this article.}

'grabbing green,' or the alignment of 'systemics (neoliberal discourse and institutional performance), logics (legitimizing practices that justify action), and instruments (techniques, calculations, metrics) that facilitate the abstraction and alienation required by markets created to exchange the virtual and material commodities produced from a re-envisioning of nature' (2013, 11). This window into these discursive 'alignments' thus illustrates the material consequences of development discourse within the spatial and social margins of biofuel commodity formation and the emerging politics of private sector-led initiatives (Moore 2010; Lyons and Westoby 2014).

One of the main conclusions from this work is the attention drawn to the critical framing of private sector biofuel firms as a 'post-developmentalist agent.' In reality, the line between the private and public sector in rural development has become increasingly ambiguous as partnerships between NGOs, aid agencies and private firms have proliferated over the past 25 years (Bebbington et al. 2008). However, what we see in this study is the private sector firms evolving their development discourse, particularly in periods of political crisis and where the state and civil society are relatively absent, to fit their emerging role as central in rural development. While few are in a position to do this in isolation without some sort of state and civil society funding or logistical support, private sector development is now a mainstay in rural areas across the global south (Carmody 2011). This privatization is important as persistent ethical questions arise concerning both private sector accountability to deliver on development benefits and the material consequences of programmes worldwide, whilst also raising serious issues of the permanence of benefits after the company leaves (Hunsberger 2010; Baka 2012).

Globally, the private sectors' use of development discourse attracts needed foreign capital in a politically-charged climate of the 'global land grab' (Hunsberger and Ponte 2014; Baka 


\section{Please note: This is an unedited pre-print version of this article.}

2014; Sassen 2014). On the domestic front, this discourse helps favourable investment policies, such as new investment laws, tax breaks, and pro-business land reforms (Hunsberger and Ponte 2014). The promotion of income generation and small-scale development also helps firms to negotiate their position in rural areas. Local mayors are also seen performing development discourse as a way to gain social and political capital while also acting as key intermediaries and brokers of land acquisitions. However, what was promoted as sustainable and inclusive biofuel development did not materialize with many local resource users (Peet and Watts 2004), and within a few years, biofuel firms began closing their doors or shifting operations to other crops, leaving many rural Malagasy with unfulfilled promises. These disruptions only helped to increase tensions amongst villagers and with the firm, and marginalising already vulnerable livelihoods, especially those relocated migrants who remain in areas with few viable income options. This snapshot reflects other such cases the highlight biofuel firms' ability to access fertile plots in areas with generally low potential for agricultural productivity and the way in which they promote labour opportunities as an attempt (albeit not so successful) to ease social tension over land and other resources (Gingembre 2015). Such scenes of fractured resistance 'from below' and biofuel firms' uneven responses are unearthing tensions across Madagascar (Medernach et al. 2011; Franchi et al. 2013; Widman 2014). Firms are trying to change their business strategies in a postbiofuel landscape, however, they must do so in a fragile landscape of emerging politics. Some of this recalibration will translate in the remaining firms, such as Vertifuel, closing their doors on biofuels altogether or finding other agricultural crops to produce for export. Either way, one can comfortably say that the biofuel landscape has gone bust in Madagascar. Another contribution this work makes is the better understanding social and material relations through reflecting a deepening and widening of commodity relations (Moore 2010; Corson et 
Please note: This is an unedited pre-print version of this article.

al. 2013). The consequences of this are significant as the failed development schemes stir up social unrest and potential rural differentiation as migrant workers are seen as being aligned with foreign biofuel firms by other established villagers (mainly herders). Paradoxically, migrant labourers (non-locals) are able to capture some of the merger benefits of biofuels due to their availability during the off-season, while overall the majority of local villagers see very little impact on their livelihoods. In the end, it is really a few local mayors who end up being the lasting beneficiaries of the biofuel markets as they are able to negotiate the land deals and accrue some temporary 'political clout' while working with the firm. This asks us once again to rethink private sector development and the homogeneous framing of beneficiaries. The study allows us to see more clearly the socio-economic inequality and the distribution of benefits.

The results of this study correspond to other recent biofuel studies which have demonstrated similar results including early returns of benefits back to local communities during the establishment of the plantation, but the perks of employment and other development services withered away as the firm's initial capital was spent (German et al. 2011; Levers 2011). These findings of the shortcomings of private sector development also resonate with largescale mining 'offset' compensation schemes (Duffy 2006; Seagle 2012), and conservation benefits in bioprospecting (Neimark 2012) and ecotourism and ecosystem services, whereas the discursive framing of firms as primary agents of sustainable development has material implications of accountability primarily at the local and national scale.

The empirical and theoretical findings of this study, however, have implications beyond that of just natural resource-based industries. For example, understanding the multiplicity of voices through discursive performance provide a window into how the increasing dependence on private sector growth for the delivery of local development services, such as poverty 


\section{Please note: This is an unedited pre-print version of this article.}

reduction, access to healthcare and education. This article harnesses the strengths of cultural political economy (framing from above) and political ecology (framing from below). In doing so, it provides an integrated theoretical and analytical toolkit which can draw specific attention to the alignment of 'economic' discourse, logics and instruments and the material consequences in specific areas of intervention. What would a 'Cultural Political Ecology' approach to private sector-led rural healthcare or education look like? Hopefully the results of this research will facilitate more studies which integrate the synergetic approaches in political ecology and cultural political economy and add to the gap in studies about private sector rural development in the global south.

\section{Acknowledgements:}

This research was generously funded by a National Geographic Society Committee for Scientific Research Grant (No. 9222-12) and a Land Deal Politics Initiative (LDPI) grant. Special thanks to Michael Carolan and five anonymous reviewers for their suggestions. I want to thank Andre Teyssier, Rivo Andrianirina- Ratsialonana, and Perrine Burnod for comments on earlier parts of this article. I also want to thank Tim Healy, and Samantha Patton and Obinna Anejionu for their professional research support.

\section{REFERENCES}

Adger, W. N., T.A. Benjaminsen, K. Brown and H. Svarstad, 2001. Advancing a political ecology of environmental discourses. Development and Change, 32 (4), 681-715.

Andrianirina-Ratsialonana, R., Ramarojohn, L., Burnod, P. and A. Teyssier, 2011. After Daewoo? Current status and perspective of large-land scale acquisitions in Madagascar. Rome: Observatoire du Foncier à Madagascar, CIRAD, ILC.

Argent N, Measham T, 2014, New rural economies: Introduction to the special themed issue. Journal of Rural Studies, 328-329.

Baka, J., 2014. What Wastelands? A Critique of Biofuel Policy Discourse in South India. Geoforum, 54: 315-23.

BAMEX, 2008. Madagascar: Business and Market Expansion (BAMEX) August 2004August 2008 Final Report. Washington, DC: Chemonics International.

Bebbington, A J., Hickey, S., Mitlin, D. 2008. Can NGOs Make a Difference?: The Challenge of Development Alternatives. Zed Books. 
Please note: This is an unedited pre-print version of this article.

Birch, K., and D. Tyfield. 2013. 'Theorizing the Bioeconomy: Biovalue, Biocapital, Bioeconomics or . . What? Science, Technology, \& Human Values, 38 (3): 299-327.

Borras, S.M. and J.C. Franco, 2012. Global Land Grabbing and Trajectories of Agrarian Change: A Preliminary Analysis'. Journal of Agrarian Change, 12 (1): 34-59.

Bruce J., Fortmann, L. and C. Nhira, 1993. Tenures in Transition, Tenures in Conflict: Examples from the Zimbabwe Social Forest. Rural Sociology, 58 (4): 626-642.

Burnod, P., Gingembre, M. and R. Andrianirina-Ratsialonana, 2013. Competition over Authority and Access: International Land Deals in Madagascar. Development and Change, 44 (2): 357-79.

Callon M, 1998. Introduction: the embeddedness of economic markets in economics. The Sociological Review 46 1-57.

Carmody, P. 2011. The New Scramble for Africa. Cambridge, UK, and Maiden, MA: Polity Press.

Cocklin, C. I. Bowler, C. 2002. Bryant Introduction: sustainability and rural systems I. Bowler, C. Bryant, C. Cocklin (Eds.), The Sustainability of Rural Systems: Geographical Interpretations, Kluwer, Dordrechtpp. 1-12.

Corson, C., 2011. Territorialization, Enclosure and Neoliberalism: Non-state Influence in Struggles over Madagascar's Forests. Journal of Peasant Studies, 38 (4): 703-726.

Corson, C. MacDonald, K.I. and B. Neimark, 2013. Grabbing "Green": Markets, Environmental Governance and the Materialization of Natural Capital. Human Geography, 6 (1): $1-15$.

Cotula, L., 2012. The International Political economy of the Global Land Rush: A Critical Appraisal of Trends, Scale, Geography and Drivers. Journal of Peasant Studies, 39 (3-4): 649-80.

Dauvergne, P. and K.J. Neville, 2010. Forests, Food, and Fuel in the Tropics: The Uneven Social and Ecological Consequences of the Emerging Political Economy of Biofuels Journal of Peasant Studies, 37 (4): 631- 60.

Deininger, K. and S. Jin, 2007. Securing Property Rights in Transition: Lessons from Implementation of China's Rural Land Contracting Law. Policy Research Working Paper Series 4447, Washington DC: World Bank.

Deltombe T., 2012. Les fantômes de Madagascar: La France, acteur-clé de la crise malgache http://www.monde-diplomatique.fr/2012/03/DELTOMBE/47470_[accessed on 2 April 2012]

Duffy, R. 2006. NGOs and Governance States: The Impact of Transnational Environmental Management Networks in Madagascar. Environmental Politics, 15 (5): 731-49. 
Please note: This is an unedited pre-print version of this article.

Evers, S.J., Burnod, P., Andrianirina-Ratsialonana, R and A. Teyssier, 2011. Foreign Land Acquisitions in Madagascar: Competing Jurisdictions of Access Claims. In African Engagements: Africa Negotiating an Emerging Multi-Polar World, eds. T. Dietz, K.

Havnevik, M. Kagg, and T. Oestigaard, 110-132. Leiden-Boston: Brill AEGIS Book Series.

Fairbairn M, 2014, 'Like gold with yield': Evolving intersections between farmland and finance. Journal of Peasant Studies, 41 777-795

Feeley-Harnik G, 1991 Green Estate Washington, DC: Smithsonian Institution Press.

Ferguson, J. and A. Gupta, 2002. Spatializing States: Toward an Ethnography of Neoliberal Governmentality. American Ethnologist, 29 (4): 981-1002.

Forsyth, T. 2003. Critical Political Ecology: The Politics of Environmental Science, London and New York: Routledge.

Foucault, M., 1978/1991. 'Governmentality'. In The Foucault Effect. Studies in Governmentality, eds G. Burchell, C. Gordon and P. Miller, 87-104. Chicago: University of Chicago Press.

Franchi, G., Rakotondrainibe. M., Raparison E.H. and P. Randrianarimanana, 2013. 'Land Grabbing in Madagascar: Echoes and Testimonies from the Field' Re: Common Collectif pour la Défense des Terres Malgaches - TANY, Solidarité des Intervenants sur le Foncier SIF. Antananarivo, Madagascar.

German, L., Mandondo, A., Paumgarten, F. and J. Mwitwa, 2014. Shifting Rights, Property and Authority in the Forest frontier: 'Stakes for Local Land Users and Citizens. Journal of Peasant Studies, 41 (1): 51-78.

Gingembre M, 2015. 'Resistance or participation? Fighting against corporate land access amid political uncertainty in Madagascar. Journal of Peasant Studies, 1-24.

GRAIN, 2013. Land Grabbing for Biofuels Must Stop: EU Biofuel Policies are Displacing Communities and Starving the Planet. Against the Grain, February.

http://www.grain.org/article/entries/4653-land-grabbing-for-biofuels-must-stop [accessed on 1 June 2013]

Harvey, D., 2003. The New Imperialism. Oxford: Oxford University Press.

Hunsberger C, 2010. The politics of Jatropha-based biofuels in Kenya: convergence and divergence among NGOs, donors, government officials and farmers. The Journal of Peasant Studies, 37: 939-962

Hunsberger, C., Ponte, S., 2014. 'Sustainable' Biofuels in the Global South. Geoforum, 54: 243-247.

Igoe J., 2013. Consume, Connect, Conserve: Consumer Spectacle and the Technical Mediation of Neoliberal Conservation's Aesthetic of Redemption and Repair. Human Geography, 6: 16-28 
Please note: This is an unedited pre-print version of this article.

Jessop B, 2004. Critical Semiotic Analysis and Cultural Political Economy. Critical Discourse Studies, 1: 159-174.

Jessop B, 2013. Recovered Imaginaries, Imagined Recoveries: A Cultural Political Economy of Crisis Construals and Crisis Management in the North Atlantic Financial Crisis. In: Before and Beyond the Global Economic Crisis: Economics, Politics and Settlement Benner, M. (ed.) Cheltenham: Edward Elgar, p. 234-254.

Leach M, Mearns R., 1996. The Lie of the Land: challenging received wisdom on the African environment. Oxford: James Currey.

Li, T.M., 2007. The Will to Improve: Governmentality, Development, and the Practice of Politics. Durham: Duke University Press.

Li, T.M., 2014. What is land? Assembling a Resource for Global Investment. Transactions of the Institute of British Geographers, 39: 589-602.

Lyons K, Westoby P, 2014. Carbon Colonialism and the New Land Grab: Plantation Forestry in Uganda and its Livelihood Impacts. Journal of Rural Studies, 36: 13-21.

MacDonald K I, Corson C, 2012. 'TEEB Begins Now': A Virtual Moment in the Production of Natural Capital. Development and Change, 43: 159-184.

McConnell, W., 2002. Misconstrued Land Use in Vohibazaha: Participatory Planning in the Periphery of Madagascar's Mantadia National Park. Land Use Policy, 19 (3): 217-230.

Medernach K., Burnod P., 2013. Recompositions inattendues d'un système agraire malgache par l'agrobusiness. Etudes rurales, 1(191): 63-76.

Medernach, K., Burnod, P., and H., Rakotomalala, 2011. Large-Scale Foreign Land Acquisitions: What Interactions, Opportunities and Risks for Different Local Farming Systems? A Case-Study in Madagascar. Thesis Report with the Malagasy Land Observatory, Paris: Antananarivo and ISTOM.

Mitchell T, 2008. Rethinking Economy. Geoforum, 39:1116-1121.

Moore J W, 2000. Sugar and the Expansion of the Early Modern World-Economy: Commodity Frontiers, Ecological Transformation, and Industrialization. Review (Fernand Braudel Center) 409-433.

Moore J W, 2010. The End of the Road? Agricultural Revolutions in the Capitalist WorldEcology, 1450-2010. Journal of Agrarian Change, 10: 389-413.

Neimark, B., 2012. Industrializing Nature, Knowledge, and Labour: The Political Economy of Bioprospecting in Madagascar. Geoforum, 43(5): 580-90.

Neumann R, 2004. Making Political Ecology. London: Routledge.

Newell P, Paterson M, 2010 Climate Capitalism: Global Warming and the Transformation of the Global Economy. Cambridge University Press. 
Please note: This is an unedited pre-print version of this article.

Ogden L, Heynen N, Oslender U, West P, Kassam K-A, Robbins P, 2013. Global Assemblages, Resilience, and Earth Stewardship in the Anthropocene" Frontiers in Ecology and the Environment, 11: 341-347.

Openshaw, K., 2000. A Review of Jatropha curcas: An Oil Plant of Unfulfilled Promise. Biomass Bioenergy, 19 (1): 1-15.

Ottino P, 1998. Les Champs de l'ancestralité à Madagascar: Parenté, Alliance et Patrimoine. Paris: Karthala Editions.

Oya C, 2007. Stories of Rural Accumulation in Africa: Trajectories and Transitions among Rural Capitalists in Senegal. Journal of Agrarian Change, 7:453-493.

Oya C, 2013, "Methodological reflections on 'land grab' databases and the 'land grab'literature 'rush'" Journal of Peasant Studies, 40:503-520.

Pandey, V.C., Singh, K., Singh, J.S., Kumar, A., Singh, B. and R. P. Singh. 2012. Jatropha curcas: A Potential Biofuel Plant for Sustainable Environmental Development Renewable and Sustainable Energy Reviews, 16 (5): 2870-883.

Peet R, Watts M, 1996, Liberation Ecology: Development, sustainability, and environment in an age of market triumphalism in Liberation Ecologies: Environment, Development and Social Movements. London: Routledge.

Peluso, N.L. and C. Lund, 2011. New Frontiers of Land Control: Introduction. Journal of Peasant Studies, 38 (4): 667-81.

Polanyi K, 1944. The Great Transformation: The Political and Economic Origins of Our Time. Boston: Beacon Press.

Raison, J-P., 1969. Note sur L'utilization des Cadastres Malgaches pour la Réalization de Cartes de Terroirs. Cahiers ORSTOM, Série Sciences Humaines VI, (3) 5-23.

Rakotondrainibe, M., 2012. Ihorombe - Fasana sy Trano Maro Noravan'ny Tozzi Green Inona ny Vaovao, 1031, Collectif Tany, Newsletter No. 20. http://terresmalgaches.info/ [accessed on 8 March 2013].

Ramaroson, M., Ramiaramana, D. and L. Ravoniarisoa, 2010. Promoting Women's Access to and Control Over Land in the Central Highlands of Madagascar. Rome: International Land Coalition and Bellville: PLAAS.

Randriamaro, Z., 2012. Greening the Economy and Increasing Economic Equity for Women Farmers in Madagascar. The International Policy Centre for Inclusive Growth Policy Research Brief No. 34, UNDP.

Ratisimbarisoa, A., 2012. Success Stories. http://www.tozzigreen.com/?lang=en [accessed on 4 April 2012]

Robertson, M. M. 2006. The Nature that Capital Can See: Science, State, and Market in the Commodification of Ecosystem Eervices. Environment and Planning D 24 (3): 367-87. 
Please note: This is an unedited pre-print version of this article.

Sassen S. 2013. Land Grabs Today: Feeding the Disassembling of National Territory. Globalizations, 10(1): 25-46.

Schroeder, R.A., 1999. Shady Practices: Agroforestry and Gender Politics in The Gambia. Berkeley: University of California Press.

Scoones, I., 2009. Livelihoods Perspectives and Rural Development. Journal of Peasant Studies, 36 (1): 171-96.

Scoones I, Hall R, Borras Jr S M, White B, Wolford W, 2013. The Politics of Evidence: A Response to Rulli and D'Odorico. Journal of Peasant Studies, 40: 911-912.

Scott, J. C., 1989. Seeing Like a State: How Certain Schemes to Improve the Human Condition have Failed. New Haven, CT: Yale University Press.

Seagle C, 2012. Inverting the impacts: Mining, conservation and sustainability claims near the Rio Tinto/QMM ilmenite mine in Southeast Madagascar. Journal of Peasant Studies, (39) 447-477.

Stott P A, Sullivan S, 2000. Political Ecology: Science, Myth and Power. London: Arnold.

Teyssier A., 2010. Decentralizing Land Management, the Experience of Madagascar. Perspective no. 4. France CIRAD.

Teyssier, A., Andrianirina- Ratsialonana R.., Razafindralambo R. and Y. Razafindrakoto, 2008. Decentralization of Land Management in Madagascar: Process, Innovations, and Observation of the First Outcomes. Paper presented at the Annual World Bank Conference on Land Administration, Washington, DC: World Bank.

Tsing A L, 2000. Inside the economy of appearances. Public Culture, 12: 115-144.

UNCTAD, 2011. Foreign Direct Investment in LDCs: Lessons Learned from the Decade 2001-2010 and the Way Forward. New York and Geneva: United Nations.

van Eijck, J., Romijn, H., Balkema, A. and A. Faaij, 2014. Global Experience with Jatropha Cultivation for Bioenergy: An Assessment of Socio-Economic and Environmental Aspects. Renewable and Sustainable Energy Reviews, 32 869-89.

West, P., and Carrier, J.G., 2004. Ecotourism and Authenticity: Getting Away from it All? Current Anthropology, 45 (4): 483-91.

Widman, M., 2014. Land Tenure Insecurity and Formalizing Land Rights in Madagascar: A Gender Perspective on the Certification Program. Feminist Economics, 20(1): 130-154.

World Bank, 2003. Land Policies for Growth and Poverty Reduction. A World Bank Policy Research Report. New York: Oxford University Press for the World Bank.

World Bank, 2010. Rising Global Interest in Farmland: Can it Yield Equitable and Sustainable Benefits? Washington: World Bank. 
Please note: This is an unedited pre-print version of this article.

WWF, 2011. Premiere Phase de L'etude Strategique du Development du Sector Agrocarburant a Madagascar? Platforme Agrocarburant Durable (PAD). Antananarivo: Madagascar. 